\title{
Benchmarking Transit Research in the United States
}

\author{
Richard Marshment, University of Oklahoma
}

\begin{abstract}
The national transit research program in the United States commands fewer resources than research on other surface transportation modes. In real dollars, expenditures on the national transit research program declined over the past six years. While the Safe, Accountable, Flexible, and Efficient Transportation Equity Act of 2005 reverses this trend by increasing transit research funding over the next five fiscal years, transit research funding still lags aviation, highways, and railroads. The low priority assigned transit research at the national level is also prevalent at the state, transit industry, and university levels.

In an effort to focus resources on the transit industry's most pressing needs, the Federal Transit Administration (FTA) has adopted a strategic transit research plan that sets forth five goals: provide leadership, increase ridership, improve operating and capital efficiency, improve safety and emergency preparedness, and protect the environment and promote energy independence. FTA charts strategies to achieve these goals but must do so with most of its research budget earmarked to specific projects. Technology issues dominate the national transit research program.
\end{abstract}

\section{Introduction}

The Safe, Accountable, Flexible, and Efficient Transportation Equity Act of 2005 (SAFETEA-LU) set two new milestones: it was the largest surface transportation bill ever, and it contained more earmarked projects than any of its predecessors. 
A less noticed feature of SAFETEA-LU was its reversal of the long-term decline in federal support for transit research. Using an assessment method called benchmarking, a review of past appropriations and expenditures and transit research action plans at the federal and state levels shows a declining fiscal effort toward transit research, a strong emphasis on transit technology, especially electric-drive buses, and the emergence of state-level transit research programs cooperatively conducted by state departments of transportation and university-based transportation research centers.

Benchmarking is the process of establishing a position by measuring distances from known locations. This surveying concept has many applications including the analysis of research programs (Committee on Science, Engineering, and Public Policy 1999). This article benchmarks transit research in the United States. The methodology compares the resources and focus of transit research in the United States to other modal research programs in the United States and the United Kingdom. The benchmark population includes the modal administrations of the U.S. Department of Transportation (U.S. DOT), other federal departments, the American Public Transportation Association (represents the transit industry), state departments of transportation, and the United Kingdom Department for Transport. While transit research occurs in organizations other than those included in the benchmark population, the sample used in this study is sufficient to determine the relative position of transit research compared to other transportation research activities. Performance measures include expenditures on research, discretionary spending on research, and research strategies, plans, and programs. This benchmarking report does not address the quality of research products.

\section{Data Sources for the Benchmark Population}

Principal data sources for this study include the U.S. DOT's Research, Development, and Technology Plan (Volpe National Transportation System Center 2003); research plans of the U.S. DOT's modal administrations; published budgets of federal departments and departmental subdivisions; tables on earmarked expenditures developed by Wachs and Brach (2004); published transit research programs of a sample of state departments of transportation; the California Department of Transportation strategic research plan [Division of Research and Innovation (DRI) 2000]; the American Public Transportation Association strategic research plan (APTA 2001); and the U.K. Department for Transport's Evidence and Research Strategy (DfT 2002). 
Differences in definitions and missions limit direct comparisons among all these organizations. The modal administrations within the U.S. DOT constitute a good benchmark population since all engage exclusively in applied research and expenditure and organizational data, and research definitions are reasonably consistent across administrative boundaries. Some federal agencies outside the U.S. DOT with applied research programs also constitute a relevant benchmark population such as the Departments of Commerce, Housing and Urban Development, and Interior. Research definitions and budget categories can vary within this population.

The three nonfederal agencies in the benchmark population view and classify research differently than the FTA compelling use of qualitative rather than quantitative comparisons. APTA classifies studies whose intent is to influence federal policy as research. The California Department of Transportation's DRI does not classify its research expenditures into the same categories as does the U.S. DOT. The United Kingdom has a strategic transit research vision, although organizationally the U.K. Department for Transport differs substantially from the U.S. DOT and publishes a programmatic rather than line-item budget.

Financial tables in this study can refer to budgeted amounts, appropriations, and expenditures, depending on data availability. Budgeted amounts are monies listed in enabling legislation such as SAFETEA-LU. Appropriations refer to monies Congress makes available to the executive branch for spending; expenditures refer to monies actually spent by an agency. These values can be different.

\section{Expenditures on National Transportation and Transit Research Programs}

While total outlays by the U.S. DOT are larger and growing more rapidly than other federal departments in the benchmark population (Figure 1), research expenditures lag the Department of Commerce, which has the smallest total budget of the four federal departments (Figure 2) but has two subunits, the National Institute of Standards and Technology and the National Oceanographic and Atmospheric Administration, with research missions. U.S. DOT spends more on research than the Departments of Housing and Urban Development or Interior. Note the annual variation in U.S. DOT research funding in Figure 2. After normalizing research expenditures to show fiscal effort, and ignoring the Department of Commerce, which spends a large proportion of its funds on research due to its 


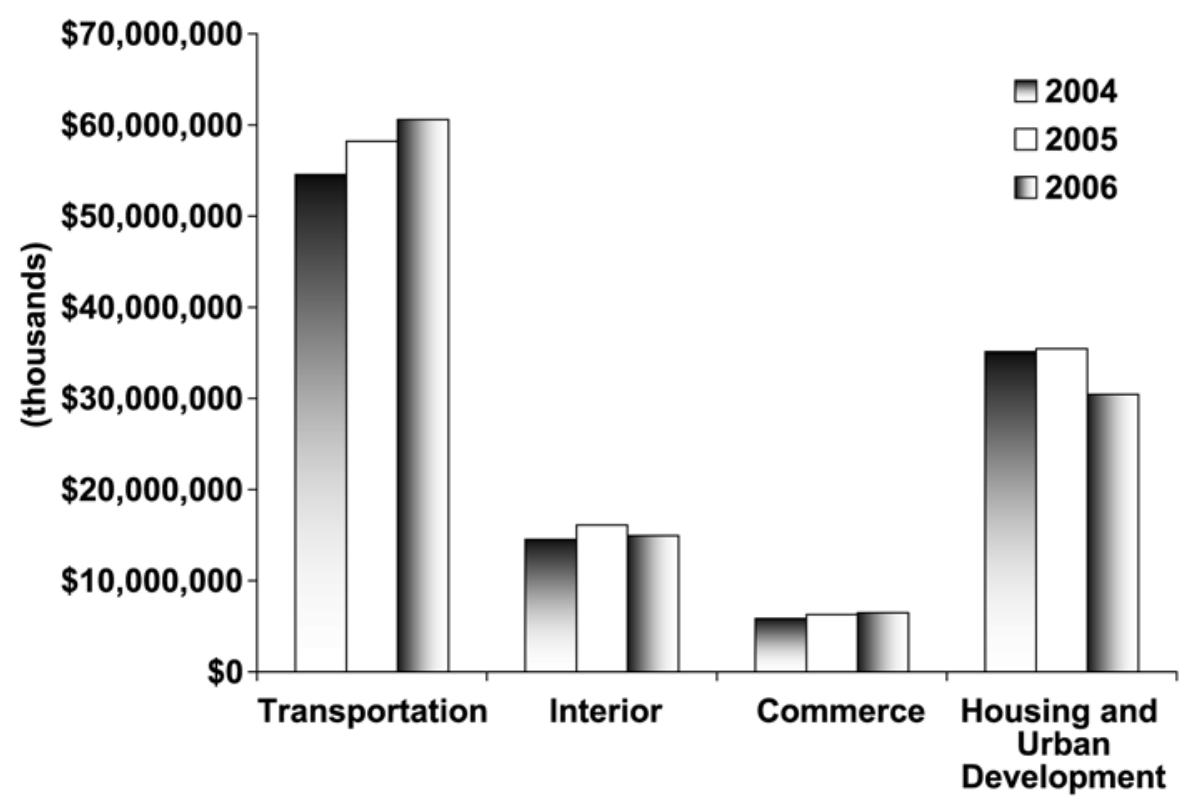

Federal Department

Figure 1. Total Outlays by Federal Department (FY 2004-2006)

Total Budget (thousands)

\begin{tabular}{lrrr}
\hline Department & 2004 & 2005 & 2006 \\
\hline Transportation & $\$ 54,547,000$ & $\$ 58,215,000$ & $\$ 60,585,000$ \\
Interior & $\$ 14,526,118$ & $\$ 16,124,330$ & $\$ 14,957,928$ \\
Commerce & $\$ 5,855,000$ & $\$ 6,283,000$ & $\$ 6,507,000$ \\
Housing and Urban Development & $\$ 35,112,000$ & $\$ 35,446,000$ & $\$ 30,443,000$ \\
\hline
\end{tabular}

Note: FY 2004 data report actual outlays; FY 2005 data report projected outlays; and FY 2006 data report requested outlays.

Source: Department of the Interior. www.doi.gov/budget/2006/06Hilites/A001.pdf. Accessed May 5, 2005, p. A-15. Department of Housing and Urban Development. www.hud. gov/about/budget/fy06/fy06budget.pdf. Accessed April 29, 2005, p. 18. Department of Commerce. www.whitehouse.gov/omb/budget/fy2006/commerce.html. Accessed May 2, 2005. Department of Transportation. http://www.dot.gov/bib2006/tables.html\#db. Accessed May 2, 2005. 


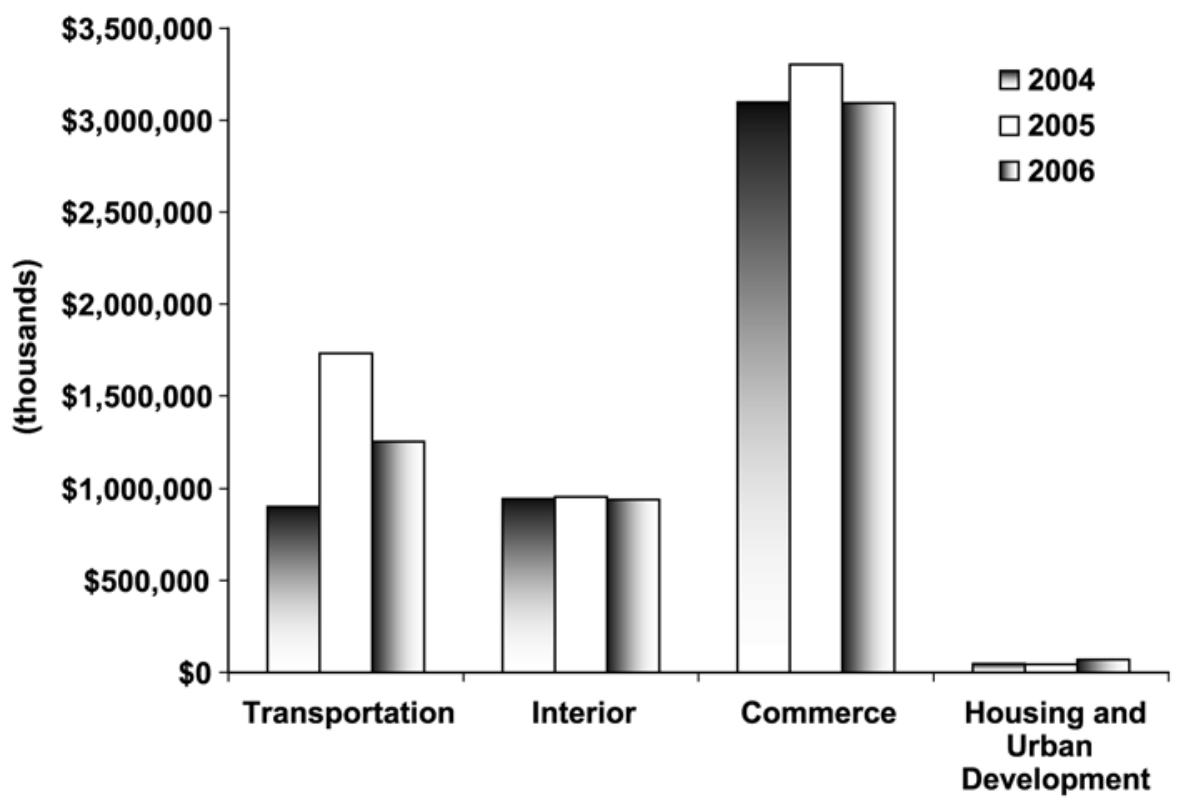

Federal Department

Figure 2. Research Outlays by Federal Departments (FY 2004-2006)

Research Budgets (thousands)

\begin{tabular}{lrrr}
\hline Department & 2004 & 2005 & 2006 \\
\hline Transportation & $\$ 902,000$ & $\$ 1,731,000$ & $\$ 1,256,000$ \\
Interior & $\$ 945,001$ & $\$ 955,927$ & $\$ 940,521$ \\
Commerce & $\$ 3,097,000$ & $\$ 3,304,000$ & $\$ 3,093,000$ \\
Housing and Urban Development & $\$ 47,000$ & $\$ 45,000$ & $\$ 70,000$ \\
\hline
\end{tabular}

Note: All amounts refer to research outlays. FY 2004 data report actual outlays; FY 2005 data report projected outlays; and FY 2006 data report requested outlays. All budget items with the term "research" in the title from the sources cited are included in the chart. Source: Department of Commerce, www.whitehouse.gov/omb/budget/fy2006/commerce.html. Accessed May 2, 2005. Includes NOAA and NIST research expenditures. Department of Interior. www.doi.gov/budget/2006/06Hilites/A001.pdf. Accessed May 5, 2005, pp. A-2 (oil spill cleanup research), A-3 (USGS surveys \& research). www.doi. gov/budget/2005/05Hilites/A001.pdf. Accessed April 29, 2005, pp. A-2.

Department of Housing and Urban Development. www.hud.gov/about/budget/fy06/fy06budget.pdf. Accessed April 29 2005, p. 17.

Department of Transportation. www.whitehouse.gov/omb/budget/fy2006/pdf/appendix/ dot.pdf. Accessed May 2, 2005. 
two research units, Figure 3 indicates the Interior Department spends a higher proportion of its budget on research than do the Departments of Transportation and Housing and Urban Development combined.

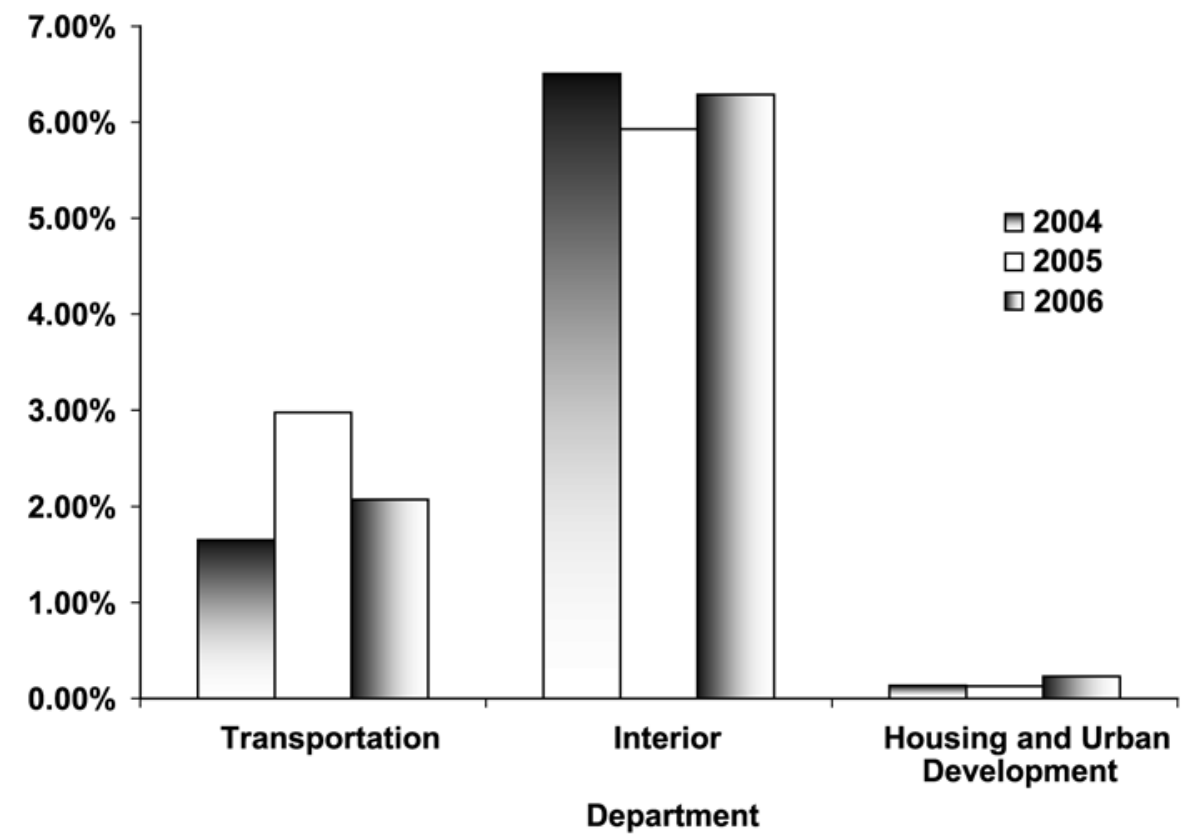

Figure 3. Percentage of Federal Departmental Budgets Expended on Research (FY 2004-2006)

Percentage of Budget Expended on Research

\begin{tabular}{lccc}
\hline Department & 2004 & 2005 & 2006 \\
\hline Transportation & $1.65 \%$ & $2.97 \%$ & $2.07 \%$ \\
Interior & $6.51 \%$ & $5.93 \%$ & $6.29 \%$ \\
Housing and Urban Development & $0.13 \%$ & $0.13 \%$ & $0.23 \%$ \\
\hline
\end{tabular}

Source: Derived from Figures 1 and 2.

Figure 4 compares the budgets of U.S. DOT's four modal administrations, the Federal Aviation Administration (FAA), the Federal Highway Administration (FHWA), 
the Federal Railroad Administration (FRA), and the Federal Transit Administration (FTA). Highway-related research substantially exceeded the research budgets for transit, aviation, and railroads. Highway research would be even more dominant if expenditures by the National Highway Traffic Safety Administration and the Federal Motor Carrier Safety Administration were included. Across all modes, research budgets in actual dollars declined or remained level between 2001 and 2003.

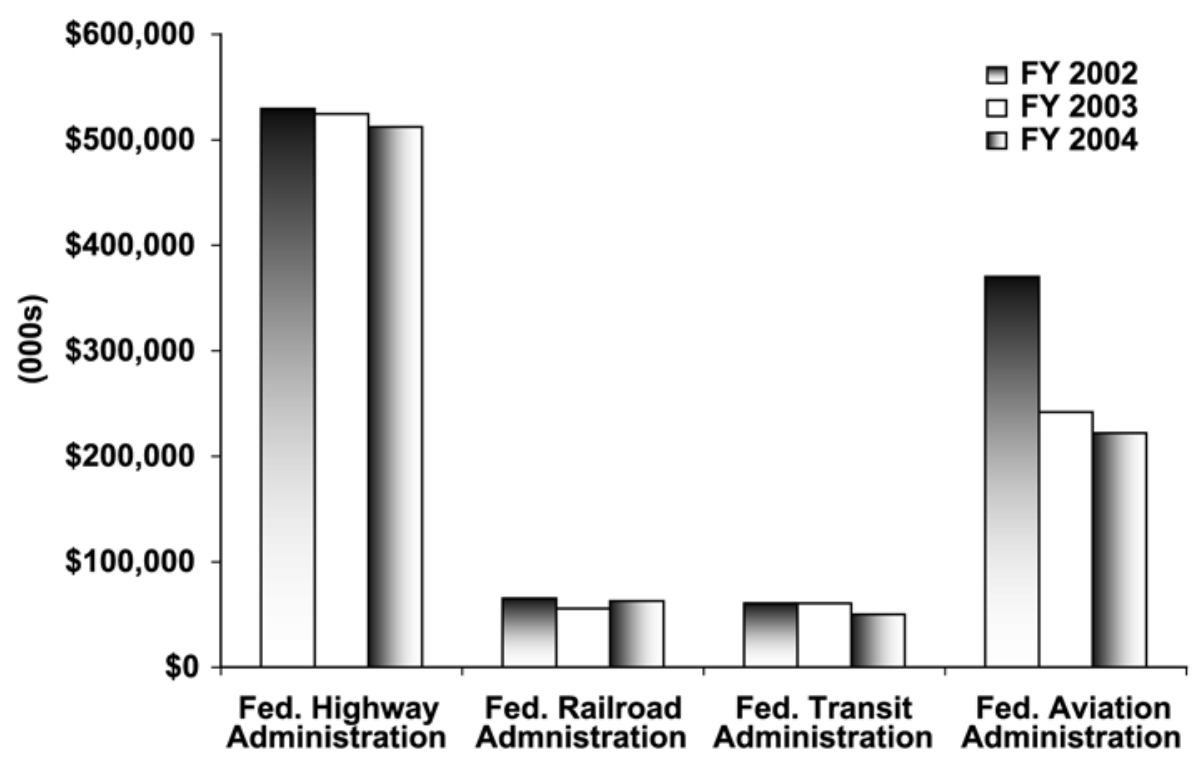

Figure 4. Research Budgets for Modal Administrations within U.S. DOT (FY 2002-2004)

\begin{tabular}{lrrr} 
& \multicolumn{3}{c}{${\text { Fiscal } \text { Year }^{\mathrm{a}}}^{\mathrm{c}}$} \\
& $2002^{\mathrm{b}}$ & \multicolumn{1}{c}{$2003^{\mathrm{c}}$} & $2004^{\mathrm{c}}$ \\
\hline Federal Highway Administration & $\$ 529,494$ & $\$ 524,403$ & $\$ 512,433$ \\
Federal Railroad Administration & $\$ 65,408$ & $\$ 55,717$ & $\$ 62,684$ \\
Federal Transit Administration & $\$ 60,770$ & $\$ 60,542$ & $\$ 50,090$ \\
Federal Aviation Administration & $\$ 370,303$ & $\$ 241,922$ & $\$ 221,859$ \\
\hline
\end{tabular}

a. All figures in thousands of dollars.

b. Appropriated amount.

c. Budgeted amount.

Source: Volpe National Transportation System Center. 2003. Research, development, and technology plan, 5th ed. Department of Transportation, p. C-1. 
Figure 5 indicates that FTA concentrated its research activity in the area of technology, with less in research and development and no budget at all for facilities. This contrasts with other modal administrations where research and development played a dominant role.

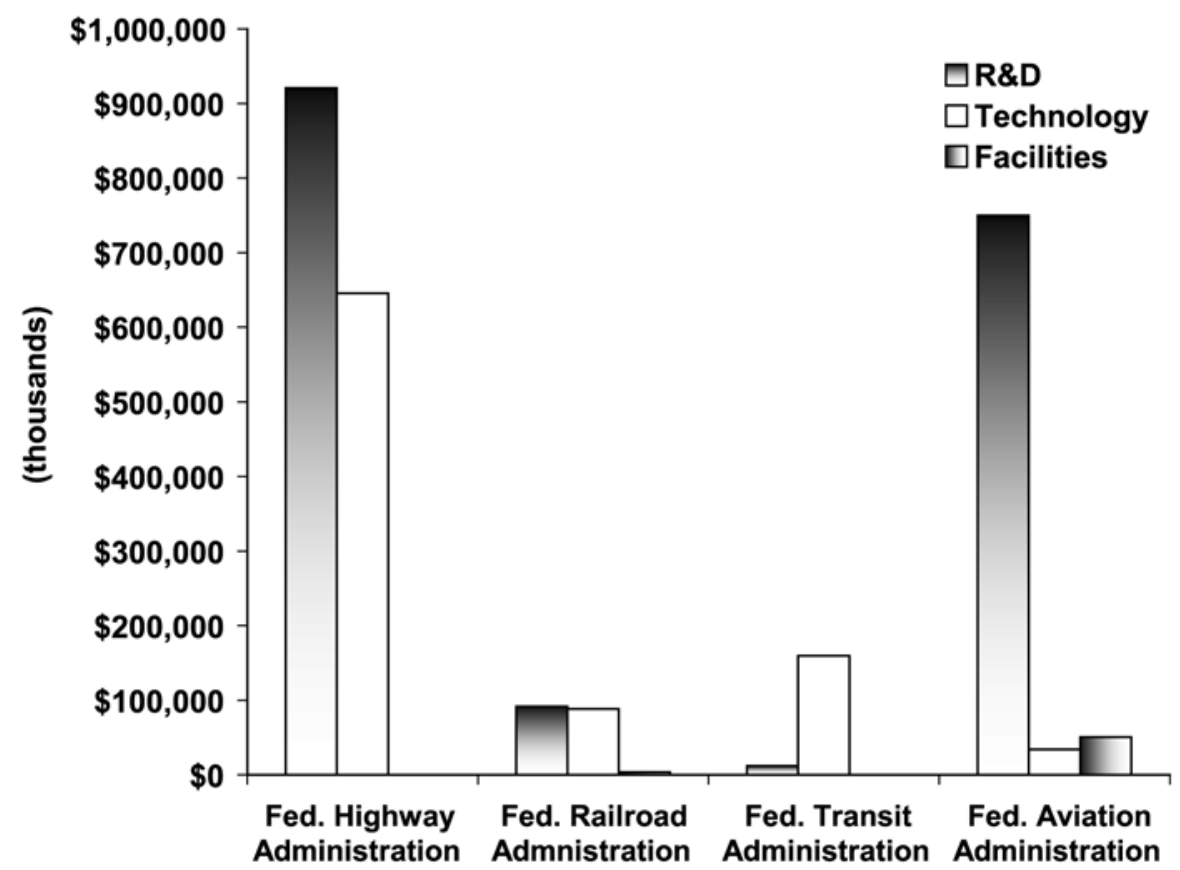

Figure 5. Modal Administration Research Budgets by Type of Research (FY 2002-2004)

\begin{tabular}{lrrr} 
& $\begin{array}{r}\text { Research and } \\
\text { Development }\end{array}$ & Technology & Facilities $^{\text {a }}$ \\
\hline Federal Highway Administration & $\$ 920,803$ & $\$ 645,527$ & $\$ 0$ \\
Federal Railroad Administration & $\$ 91,584$ & $\$ 88,450$ & $\$ 3,775$ \\
Federal Transit Administration & $\$ 11,852$ & $\$ 159,550$ & $\$ 0$ \\
Federal Aviation Administration & $\$ 749,888$ & $\$ 33,846$ & $\$ 50,350$ \\
\hline
\end{tabular}

a. Appropriations and budget authorizations in thousands of dollars.

Source: Volpe National Transportation System Center. 2003. Research, development, and technology plan, 5th ed. Department of Transportation, p. C-1. 
Again normalizing for fiscal effort, Figure 6 shows the FRA makes the greatest research effort while FTA makes the least effort. Research effort declined in all the modal administrations over the two years examined even though three of them saw increases in their total budgets.

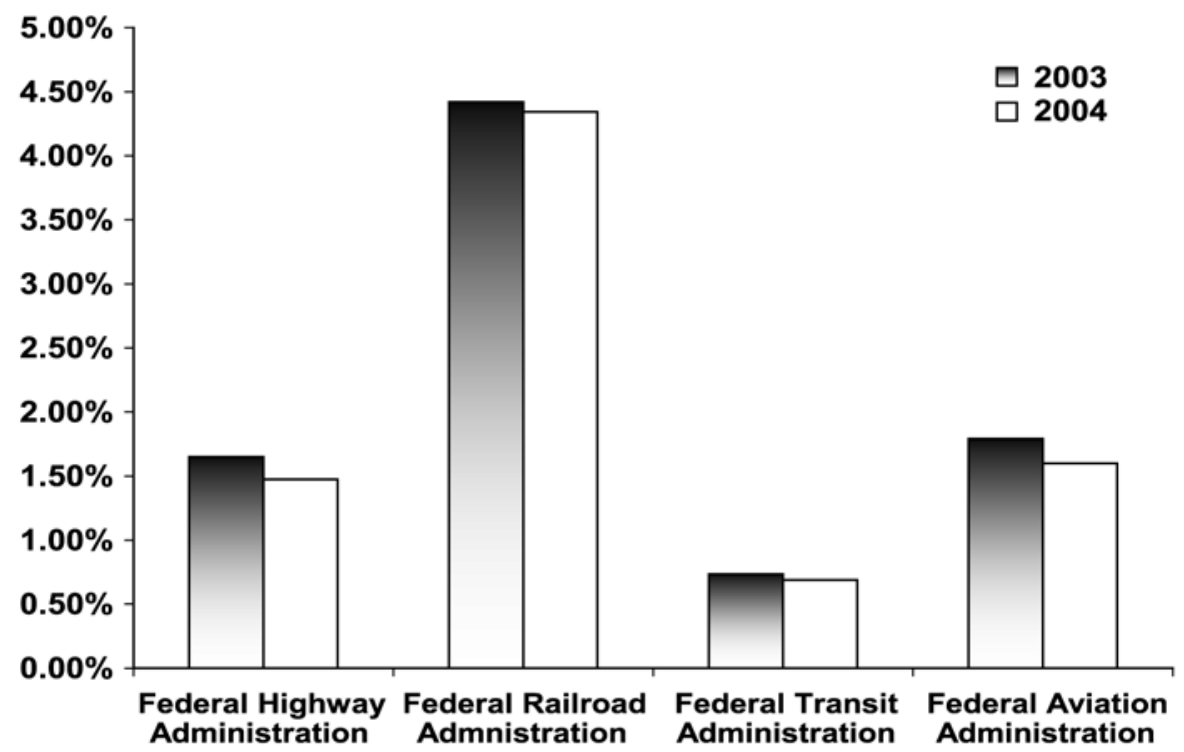

\section{Figure 6. Percentage of Modal Administration Budget Dedicated to Research (FY 2003-2004)}

Total Budget by Fiscal Year ${ }^{\mathrm{a}}$ (000s)

\begin{tabular}{lrr}
\hline & 2003 & 2004 \\
\hline Federal Highway Administration & $\$ 31,805,000$ & $\$ 34,764,000$ \\
Federal Railroad Administration & $\$ 1,261,000$ & $\$ 1,443,000$ \\
Federal Transit Administration & $\$ 8,241,000$ & $\$ 7,266,000$ \\
Federal Aviation Administration & $\$ 13,510,000$ & $\$ 13,873,000$ \\
\hline
\end{tabular}

a. Refers to amount authorized (FY 2005) or amount appropriated (FY2004).

Source: Federal Highway Administration. http://www.dot.gov/bib2005/fhwa.pdf. Accessed May 6, 2005. Federal Railroad Administration. http://www.dot.gov/bib2005/fra.pdf. Accessed May 6, 2005. Federal Transit Administration. http://www.dot.gov/bib2005/fta.pdf. Accessed May 6, 2005 Federal Aviation Administration. http://www.dot.gov/bib2005/faa.pdf. Accessed May 6, 2005. Research budgets are taken from Figure 4 . 
A key consideration in assessing the national transit research program is determining the degree to which control over budget priorities lies within the agencies. Wachs and Brach (2004) analyzed fiscal years 1992-2004 U.S. DOT modal administration research budgets to determine how much was earmarked to specific projects. Figure 7 summarizes their findings. FTA's earmarked research activities were far greater than the other two modal administrations. In some years earmarked transit research projects represented more than 90 percent of FTA's total research budget. SAFETEA-LU continues the trend toward earmarking research funding and expands it to other modal administrations; FHWA's entire research budget was earmarked (purpose and recipient) or designated for a particular purpose.

SAFETEA-LU reversed a long pattern of stable or declining surface transportation research expenditures. Table 1 lists SAFETEA-LU authorized funding for each of FTA's research program categories. Not known at this time is the degree to which FTA's future research program will be determined by earmarked projects. In FY 2006 Congress provided funds above the FY 2006 authorized level so that FTA would have some discretion within its research program. The numbers in parentheses in Table 1 indicate the amount of authorized spending that is earmarked. The FY 2006 column shows authorized spending and appropriation earmarks whereas FY 2007-FY 2009 reflect only authorization earmarks.

\section{Table 1. FY 2006-2007 FTA Research Program Funding Levels (in thousands)}

\begin{tabular}{lrrrr} 
Program & $\mathbf{2 0 0 6}$ & $\mathbf{2 0 0 7}$ & $\mathbf{2 0 0 8}$ & $\mathbf{2 0 0 9}$ \\
\hline National research and technology & $\$ 54,900$ & $\$ 40,000$ & $\$ 44,600$ & $\$ 48,450$ \\
(amount earmarked) & $(40,780)$ & $(22,855)$ & $(22,225)$ & $(22,615)$ \\
Fuel cell bus technology development program & 11,250 & 11,500 & 12,750 & 13,500 \\
Transit Cooperative Research Program & 9,000 & 9,300 & 9,600 & 10,000 \\
University Transportation Centers & 7,000 & 7,000 & 7,000 & 7,000 \\
Total & $\mathbf{\$ 8 2 , 1 5 0}$ & $\mathbf{\$ 6 7 , 8 0 0}$ & $\mathbf{\$ 7 3 , 9 5 0}$ & $\mathbf{\$ 7 8 , 9 5 0}$ \\
\hline
\end{tabular}

Source: FTA. Actual funding in FY 2006 funding is subject to a 1 percent rescission. Amounts in parentheses are earmarked funds and are included in the National Research and Technology amounts. 


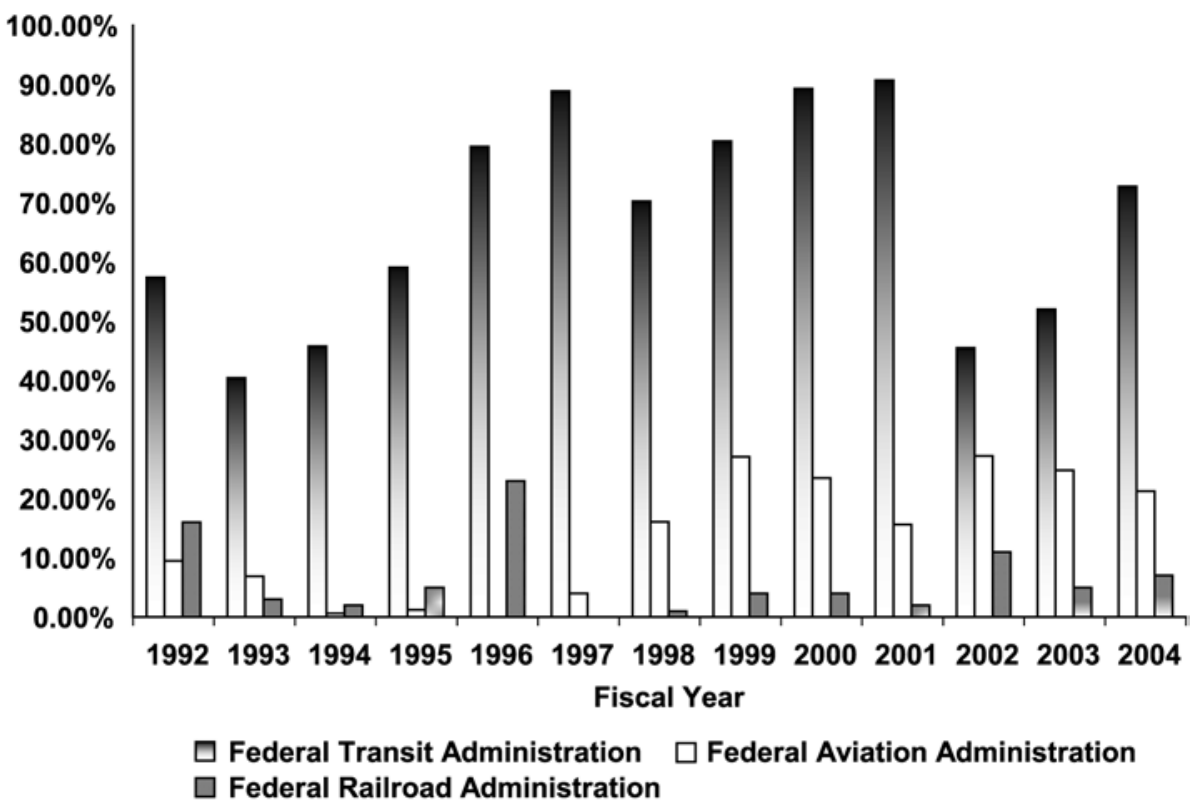

\section{Figure 7. Percentage of U.S. DOT Modal Administration Research Budgets Legislatively Earmarked to Named Projects}

\begin{tabular}{ccccccc} 
Year & $\begin{array}{c}\text { Federal Transit } \\
\text { Administration } \\
\text { Appropriation }\end{array}$ & Earmarked & $\begin{array}{c}\text { Federal Aviation } \\
\text { Administration } \\
\text { Appropriation }\end{array}$ & \multicolumn{3}{c}{$\begin{array}{c}\text { Federal Railroad } \\
\text { Administration }\end{array}$} \\
\hline 1992 & $34,511,000$ & $57.40 \%$ & $218,135,000$ & $9.50 \%$ & $22,331,000$ & $16.00 \%$ \\
1993 & $24,000,000$ & $40.40 \%$ & $230,000,000$ & $6.90 \%$ & $25,205,000$ & $3.00 \%$ \\
1994 & $26,175,000$ & $45.80 \%$ & $254,000,000$ & $0.60 \%$ & $20,613,000$ & $2.00 \%$ \\
1995 & $27,004,000$ & $59.10 \%$ & $259,192,000$ & $1.20 \%$ & $20,199,000$ & $5.00 \%$ \\
1996 & $22,000,000$ & $79.50 \%$ & $185,698,000$ & $0.00 \%$ & $24,081,000$ & $23.00 \%$ \\
1997 & $22,000,000$ & $88.90 \%$ & $187,412,000$ & $4.00 \%$ & $20,092,000$ & $0.00 \%$ \\
1998 & $36,750,000$ & $70.30 \%$ & $199,183,000$ & $16.10 \%$ & $20,755,000$ & $1.00 \%$ \\
1999 & $27,500,000$ & $80.40 \%$ & $150,000,000$ & $27.10 \%$ & $22,364,000$ & $4.00 \%$ \\
2000 & $29,500,000$ & $89.30 \%$ & $156,495,000$ & $23.50 \%$ & $22,464,000$ & $4.00 \%$ \\
2001 & $29,435,000$ & $90.70 \%$ & $187,000,000$ & $15.60 \%$ & $25,269,000$ & $2.00 \%$ \\
2002 & $31,500,000$ & $45.50 \%$ & $195,000,000$ & $27.20 \%$ & $29,000,000$ & $11.00 \%$ \\
2003 & $31,295,250$ & $52.00 \%$ & $148,450,000$ & $24.80 \%$ & $29,134,000$ & $5.00 \%$ \\
2004 & $35,290,550$ & $72.80 \%$ & $119,439,000$ & $21.30 \%$ & $33,824,000$ & $7.00 \%$ \\
\hline
\end{tabular}

Source: Wachs, Martin, and Ann M. Brach. 2004. Earmarking in the U.S. Department of Transportation research programs. Prepared for 2005 Transportation Research Board Annual Meeting. 


\section{University and Cooperative Transportation Research}

In addition to directly sponsoring transportation research, U.S. DOT contributes funds to the Transit Cooperative Research Program (TCRP), the National Cooperative Highway Research Program (NCHRP), the Airport Cooperative Research Program (ACRP), and the University Transportation Centers (UTC) program. The cooperative research programs are managed by the Transportation Research Board (TRB), the unit of the National Academies responsible for the scientific and engineering study of transportation, with the direct participation of the federal modal agencies and governmental and private organizations.

The three cooperative research programs focus on the specific applied research needs of individual modes using a peer-driven process to identify research priorities. Technical review panels assembled by TRB reduce problem statements collected annually from state departments of transportation, transit operators, industry groups, and researchers to a small set of high priority research topics. The cooperative research programs issue requests for proposals with awards made through a competitive review process.

Congress created the UTC program in 1987 to advance U.S. transportation expertise and technology transfer. The program has both educational and research missions. Initially 10 centers were established, one in each federal region. By 2006, the program had grown to include 60 UTCs, 20 of them selected competitively and the other 40 named in the SAFETEA-LU legislation (Research and Innovative Technology Administration 2006). While several of the centers have transit research elements, only one center, the University of South Florida, has transit as its central focus. The UTC program is administered by the U.S. DOT's Research and Innovative Technology Administration (RITA). UTC grants require a dollar-fordollar match unless otherwise specified in legislation. Table 2 shows UTC funding and the amount earmarked for fiscal years 2005 through 2009.

Table 3 shows past and authorized future funding for the cooperative transportation research and UTC programs. The TCRP program is the smallest of the cooperative research programs although SAFETEA-LU will put transit research funding on a par with aviation research by FY 2009. NCHRP funding comes entirely from the states using federal highway formula funds earmarked for research. FAA provides all the funding for the ACRP and FTA provides all the funding for the TCRP. 


\section{Table 2. Authorized University Transportation Centers Funding and Earmarks (FY 2005-2009; millions)}

\begin{tabular}{lccr} 
Fiscal Year & Competitive & Earmarked & Total \\
\hline 2005 & $\$ 20^{\mathrm{a}}$ & $\$ 20$ & $\$ 40$ \\
2006 & $53^{\mathrm{a}}$ & 30 & 83 \\
2007 & 53 & 30 & 83 \\
2008 & 53 & 30 & 83 \\
2009 & 53 & 32.25 & 85.25 \\
\hline
\end{tabular}

Source: By email from RITA.

Note: The universities receiving funding identified as competitive in $\mathrm{FY} 05$ and FY06 had previously competed for UTC grants, and, because SAFETEA-LU was not passed until late in $\mathrm{FY} 05$, were grandfathered in by the legislation to continue to receive funding until recompetitions could take place during FY06. Section 5101(a)(4) of SAFETEA-LU authorizes $\$ 69.7$ million annually from the Highway Trust Fund for the UTC program. Actual amounts are reduced between 8 percent and 25 percent each year due to overobligation of the Highway Trust Fund.

\section{Table 3. Federal Funding of the UTCs and Cooperative Transportation Research Programs (FY 1999-FY 2009; millions)}

\begin{tabular}{lccccccccccc} 
& FY 99 & $\mathbf{0 0}$ & $\mathbf{0 1}$ & $\mathbf{0 2}$ & $\mathbf{0 3}$ & $\mathbf{0 4}$ & $\mathbf{0 5}$ & $\mathbf{0 6}$ & $\mathbf{0 7}$ & $\mathbf{0 8}$ & $\mathbf{0 9}$ \\
\hline TCRP $^{\mathrm{a}}$ & 8.25 & 8.25 & 8.25 & 8.25 & 8.25 & 8.25 & 8.25 & 9.0 & 9.3 & 9.6 & 10.0 \\
NCHRP $^{\mathrm{b}}$ & 27.1 & 29.1 & 30.6 & 31.5 & 27.6 & 35.35 & 33.5 & 32.7 & 32.7 & 32.7 & 32.7 \\
ACRP $^{\mathrm{c}}$ & - & - & - & - & - & - & 2.9 & 10.0 & 10.0 & 10.0 & 10.0 \\
UTC $^{\mathrm{d}}$ & 32.5 & 32.5 & 32.5 & 32.5 & 32.5 & 32.5 & 40.0 & 50.5 & 50.5 & 50.5 & 85.25 \\
\hline
\end{tabular}

Source: Transportation Research Board, Research and Innovative Technology Administration, and Federal Transit Administration.

Note: Actual funding in some years was affected by across-the-board cuts. FY 06 funding is subject to a 1 percent rescission.
a. Transit Cooperative Research Program.
b. National Cooperative Research Program.
c. Airport Cooperative Research Program.
d. University Transportation Centers Program. 


\section{Strategic Transit Research in the United States}

The national transit research program supports the mission of the U.S. DOT:

The national objectives of general welfare, economic growth and stability, and the security of the United States require the development of transportation policies and programs that contribute to providing fast, safe, efficient, and convenient transportation at the lowest cost consistent with those and other national objectives, including the efficient use and conservation of the resources of the United States (U.S. DOT 2003).

Aligning FTA's research program as well as those of the other modal administrations with the U.S. DOT's mission focuses the department's efforts on advancing executive priorities. FTA periodically publishes a strategic research plan that articulates its research program. The most recently adopted plan (FTA 2005) contains mission and vision statements as follows: “... deliver solutions that improve public transportation" and make "... public transportation the mode of choice in America." The plan offers five goals:

1. Provide transit research leadership.

2. Increase transit ridership.

3. Improve capital and operating efficiencies.

4. Improve safety and emergency preparedness.

5. Protect the environment and promote energy independence.

The first goal, provide leadership in transit research, appears in FTA's research plan as a result of a recommendation made by an advisory panel convened by TRB to assist FTA in preparing the plan (Townes 2006). This advisory panel, called the Transit Research Advisory Committee (TRAC), consists of transit industry leaders, academicians, and user representatives. FTA exercises leadership in transit research by directly funding research projects of importance to its mission, entering into partnership with public and private sector organizations, often accompanied by grants which leverage public money with contributions from these other organizations, and through the agency's power as a "convener"; that is, setting research agendas by expressing interest in a topic and assembling researchers to address it.

The second goal, increase transit ridership, is what the TRAC calls "high level," meaning FTA intends to focus research toward this end. The remaining goalsenergy independence, environmental protection, improved safety, emergency 
preparedness, and capital and operating efficiencies-suggest the criteria for identifying improvement.

The FTA strategic research plan identifies knowledge gaps, suggesting areas where a need exists for additional research effort. With respect to increasing transit ridership, FTA acknowledges incomplete understanding of the determinants of transit use, especially given the range of travel markets transit serves. A key issue in this regard is whether a single transit system can serve all markets by providing good coverage and frequent service or whether services will need to be tailored to the specific requirements of individual market segments.

A comparison of FTA's previous strategic research plan with the 2005 version shows the evolution of the agency's research philosophy. FTA's transit research vision in 1999 was "integrated transportation technology producing high quality mobility in the 21st century." The mission was "...to partner with the transportation industry in establishing preeminence in U.S. transit technology, institutions, and customer service to increase the quality and level of services" (FTA 1999). The 1999 plan emphasized innovation in the transit industry with each sponsored research project following a six-step development process leading toward implementation: research, testing, evaluation, deployment, architecture and standards, and mainstreaming. The plan listed specific research topics itemized in a detailed funding schedule with companion critical path charts, budgets for FY 2000, and milestones spanning the five-year period between fiscal years 1999 and 2003. The plan included many quantifiable performance measures such as "reduce bus and light rail dwell times by 20 percent by FY 2002...," and "increase by one percent per year the urban population within 3/4 mile of transit service...." FTA's 2005 strategic research plan contains none of this detail.

Around the world transit has been a popular and vulnerable target for terrorism. FTA treats this topic under its goal of increasing transit safety and emergency preparedness. The plan states that FTA will work with the Department of Homeland Security and the Transportation Security Administration to address transit security issues.

\section{Strategic Surface Transportation Research in the United States}

When comparing FTA's 2005 strategic research plan with those of the other surface transportation modal administrations (FRA 2002; FHWA 2003), several common priorities emerge. All of the research programs emphasize safety and security, intelligent transportation systems, leveraged federal investment, fostering innova- 
tion, "... long-term, high-cost, high-risk research with a high payoff potential...." (FHWA 2003), and building professional and institutional capacity. Other features of the plans differ.

Leadership. FHWA asserts a leadership role in virtually all aspects of highway development while both FRA and FTA present more circumscribed roles. The FRA role in particular is distinct as the organization and operating structure of U.S. railroads is a hybrid of private and public sector cooperation, competition, and regulation wherein the FRA plays different roles in different situations.

Quantifiable Performance Measures. Performance measures in strategic planning inform processes on their effectiveness and hold program managers accountable for results. They also convey how organizations value their output. Neither FHWA nor FTA publishes specific performance measures. FHWA has milestones leading to an internal research project selection process and internal and external program assessments. FTA intends to develop performance measures in a future research effort. The FRA plan provides qualitative outcome measures but no metrics.

Research Project Selection Criteria. Both FRA and FTA publish project selection criteria and processes in their strategic research plans. FRA employs a five-step process to screen and refine projects for funding on the basis of potential for improving safety while accommodating higher railroad volumes. FTA makes reference to a "graded scorecard system" that ranks projects using eight criteria. FHWA does not list criteria but does set in motion an effort to develop a project selection process supportive of strategic goals such as infrastructure preservation, safety, highway operations, and environmental protection.

Program Budgets. FRA divides its research budget approximately equally between two project categories-research and development and the next generation high speed rail technology demonstration program - for a three-year time frame. Neither FTA nor FHWA provides this level of specificity. FTA outlines a four-year budget based on SAFETEA-LU authorizations. FHWA does not propose a research budget linked to a strategic research program. The relationship between research budgets proposed by the modal administrations and Congressional earmarks is an area of concern.

Linkages to Other Modal Administrations. All the administrations deal with surface transportation so overlapping jurisdiction arises in many aspects of operations. The FTA and FRA plans in particular address these overlaps in areas such as joint use of rights-of-way, vehicle standards, and roadway crossings of railroad tracks. 
Stakeholder Involvement in Research Programs. The surface transportation modal administrations all consult regularly with external stakeholders on research priorities but to different degrees and through different processes. FHWA relies heavily on historical relationships with state departments of transportation, TRB, and highway industry groups such as the Highway Users Federation, American Trucking Association, and the Asphalt Institute of America. FRA has a similar relationship with the Association of American Railroads. In addition, FRA consults with an independent advisory panel convened through TRB consisting of representatives from the railroad industry, states, unions, universities, financial institutions, and research organizations. FTA has a close working relationship with APTA, and also seeks advice from TRAC, formed under the auspices of TRB and consisting of representatives from transit operators, university researchers, and transit user groups.

Flexibility. FHWA seems most flexible in terms of research priorities. In contrast, FRA has a clear research agenda that allows for variations in approach so long as projects comport with FRA's research priorities. FTA seems committed to projects which logically follow from the goals $\rightarrow$ objectives $\rightarrow$ strategies format of its strategic research plan.

\section{Transit Research by Nonfederal Organizations}

Non-U.S. government agencies also engage in transit research often pursuing different goals than FTA. Three case studies that illuminate alternative approaches to transit research are APTA, the United Kingdom, and the state departments of transportation.

\section{American Public Transportation Association (APTA)}

APTA is the trade organization for the transit industry in the United States. APTA published a Research and Technology Strategic Plan in August 2001 to provide "... a proactive approach with the objective to more effectively position the public transportation industry when addressing the issues associated with the integration and implementation of technology and innovation" (APTA 2001). The APTA plan is in actuality a political document proposing a research agenda for FTA and other transit research organizations:

The objective is to provide APTA with a focused plan that enables it to advocate for the public transportation industry regarding research and technology. The resultant plan identifies and prioritizes APTA's needs and interests in the area 
of research and technology in order to maximize benefits, prioritize resources, seek partnerships, and influence research practitioners; and will allow APTA to advocate for the industry's research and technology needs with Congress, TRB, Universities, Federal Government and other parties; and will provide the basis for input to the ongoing re-authorization process.

APTA lists five research priorities which contrast sharply with those of FTA: workforce development, application of technology, transit's role in the community, safety and security, and market development and service configuration. Safety and security is the only research goal specified by both APTA and FTA.

APTA further subdivides its research priorities into 38 specific topics that cover the range of current transit issues including specialized transportation, security, workforce training and diversity, marketing, sustainability, and intelligent transportation systems. These priorities evolved from a series of conferences focused on the unique characteristics of the transit industry and its research needs. Findings from these conferences identified four impediments to innovation in the transit industry. First, since transit operates in a public environment, it tends to avoid risk, making it slow to adopt new technologies and procedures. Second, transit is a small industry with limited resources. Consequently, research and innovation is often sacrificed in order to attend to the more immediate need to deliver services. Third, transit has an aging workforce and ingrained labor relationships which stymie innovation. Fourth, the public environment in which transit operates impedes embracing the cultural, organizational, and structural changes necessary for innovation to occur.

\section{United Kingdom Department for Transport}

The organizational equivalent of the U.S. DOT in the United Kingdom is the Department for Transport (DfT). The DfT published a 10-year transportation plan in 2000. This plan contained a vision of transportation in the U.K. as "... a modern, safe, high quality network that better meets people's needs and offers more choice to individuals, families, communities and businesses" (DfT 2000). The U.K. emphasizes modern, high quality public transportation, both locally and nationally, including more light rail systems and attractive bus services that are fully accessible and integrated with other types of transport; high quality park-and-ride schemes; and fully integrated public transport information, booking and ticketing systems, with a single ticket or card covering the whole journey. The Transport 2010 plan's public transport emphasis is in response to the nation's growing auto dependence, which the U.K. sees as unsustainable over the long term. 
In support of the 10-year national transportation development plan, the DfT prepared a 10-year strategic transit research plan titled Evidence and Research Strategy (DfT 2002).

The strategy is organised around a number of key themes which reflect the policy priorities of the Department: reducing road congestion; achieving sustainability; health safety and security; improving public transport; facilitating social inclusion; promoting consumer choice and managing our transport assets effectively.

The plan divides its research agenda into two categories titled "policy themes" and "cross-cutting themes." Each theme is developed in two ways leading to a set of research priorities. First, the plan explains why research on the theme is important. Then the plan identifies the strategic knowledge gaps and how the agency intends to address them. As with the U.S. DOT, the DfT seeks partnerships with other transportation research organizations including other ministries, research councils, local governments, and in particular the London region. They are listed by name in an appendix to the plan.

The DfT surface transportation research program differs from the U.S. approach in several ways, perhaps most importantly by treating all surface modes as elements of a single system. Each U.S. modal administration conducts its own research program whereas in the U.K. surface transportation research is managed by a single agency. This allows the U.K. to employ a programmatic budgeting system that deemphasizes organizational boundaries in favor of stronger linkages between governmental goals and funding decisions.

\section{State Departments of Transportation}

All state departments of transportation engage in transportation research, often through transportation research centers affiliated with one or more of the state's research universities. Populous states have more than one center. These centers work with the state departments of transportation in carrying out statewide transportation research programs including transit research. Most state transit research programs are structured around annual cycles of identifying organizational research needs and then inviting proposals to address them.

A variety of transit-related research occurs at the state level, reflecting the diversity of issues resulting from different levels of density and urbanization (Transportation Research Board 2006). The annual research problem identification and proposal solicitation process makes state-level transit research programs 
highly tactical and short range. A sample of 16 of the largest state departments of transportation revealed that all of them sponsored some type of transit research but only the California Department of Transportation (CalTrans) had a strategic research plan comparable to FTA's national strategic research plan.

The CalTrans Division of Research and Innovation (DRI) is responsible for the conduct of the department's research program. DRI published a three-year strategic research plan covering the period 2002 through 2005 (DRI 2000). The plan specifically seeks to make transit a more practical travel option, focusing on three research categories: bus rapid transit, small transit systems, and enhanced transit services. A fourth research category, passenger rail improvements, overlaps the transit programs. In structure and tone, the CalTrans surface transportation research program is more similar to the U.K. approach than it is to that of the U.S. DOT. However, California employs a line-item budget system that obscures linkages between programmatic goals and budget allocations.

\section{Comparison}

Figure 8 compares the fiscal efforts of the DfT, the U.S. DOT, and CalTrans on transit research. A departmental comparison is required since neither the DfT nor CalTrans is organized into modal subdivisions in the same manner as the U.S. DOT. Creating this figure required reconciling the respective agency budgets; the U.S. DOT budget is in a line-item format, the U.K. budget follows a programmatic structure, and the CalTrans budget is a line-item budget organized by fund and program elements of which research is not separately accounted. U.S. DOT transit research includes the FTA National Research Program, the TCRP, the National Transit Institute, and FTA's contributions to the UTC program. The CalTrans budget includes contributions to its UTC and the California Center for Innovative Transportation programs. The dollar amounts in Figure 8 may differ from those in previous figures to assure comparability with U.K. definitions of research.

Neither the United States, the U.K., nor California expends a high proportion of their transportation budgets on transit research. Of the three organizations, CalTrans makes the greatest fiscal effort toward transit research. Compared to the U.K., the U.S. DOT spends more money on transit research in absolute dollars and spends a higher proportion of its total budget on transit research. However, transit research consumes a higher proportion of DfT's total research budget. In FY 2004, transit research represented 8.8 percent of DfT's research budget compared to U.S. DOT's 5.6 percent. No comparable statistic is available for California. 


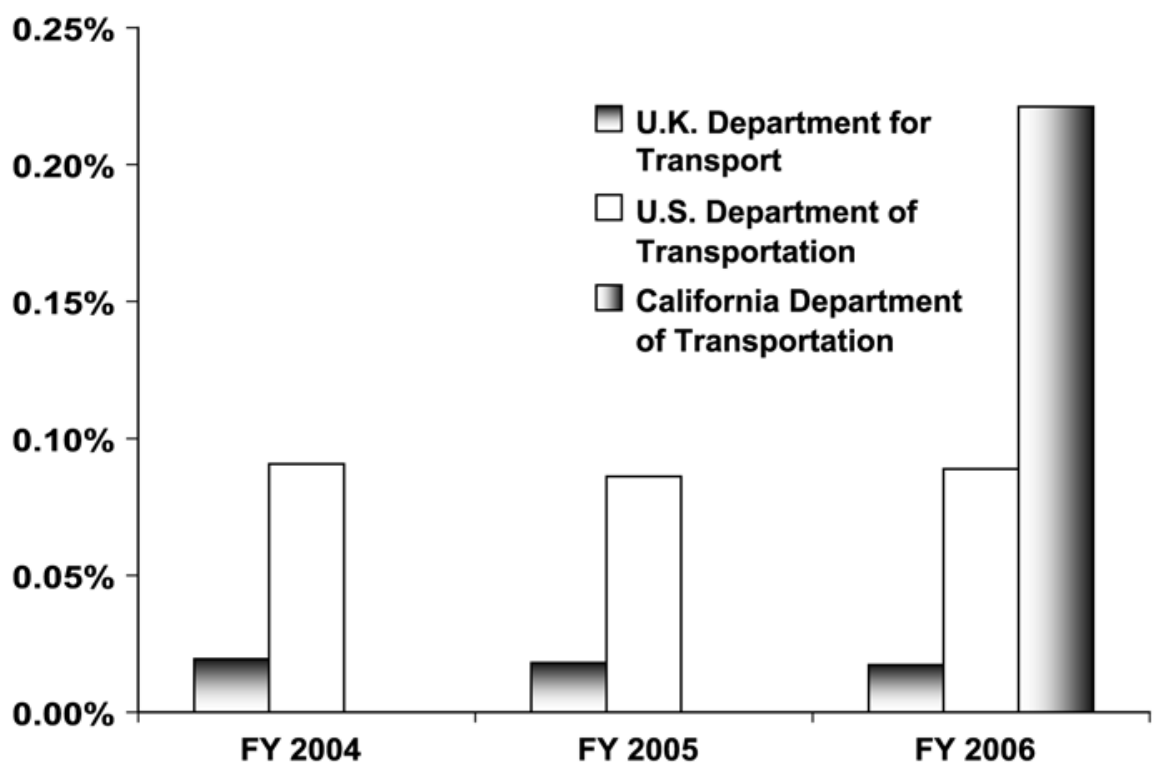

Fiscal Year

\section{Figure 8. Percentage of Department Budget Allocated to Transit Research (FY 2004-2006)}

\begin{tabular}{lcccccc} 
& \multicolumn{3}{c}{} & \multicolumn{3}{c}{$\begin{array}{c}\text { Public Transportation } \\
\text { Research Budget (millions) }\end{array}$} \\
\hline & FY 2004 & FY 2005 & FY 2006 & FY 2004 & FY 2005 & FY 2006 \\
\hline U.K. Dept. of Transport a,b,c,d & 21.6 & 23.2 & 24.2 & 4.2 & 4.2 & 4.2 \\
U.S. DOT & 54.6 & 58.2 & 60.6 & 49.5 & 50.1 & 53.8 \\
California DOT & & & 6.6 & & & 14.7 \\
\hline
\end{tabular}

a. Actual expenditures for FY 2004, budgeted for FY 2005, and planned for all other fiscal years.

b. Combination of operating and capital budgets.

c. Exchange rate of $£ 1=\$ 2$.

d. Source: HM Treasury, United Kingdom Budget. 2005. Department Expenditure Limits. www.hm-treasury.gov.uk/media/AA7/AD/bud05_chapc_252.pdf. Accessed July 13, 2005, p. 261, Table C-13.

e. Office of Management and Budget. 2005. FY 2006 Budget for U.S. DOT. www.whitehouse.gov/omb/budget/fy2006/pdf/appendix/dot.pdf. Accessed July 15, 2005, p.825.

f. Office of Management and Budget. 2005. FY 2005 Budget for U.S. DOT. www.gpoaccess.gov/usbudget/fy05/pdf/appendix/DOT.pdf. Accessed July 15, 2005, p.805.

g. Office of Management and Budget. 2004. FY 2004 Budget for U.S. DOT. a257.g.akamaitech.net/7/257/2422/03feb20030900/www.gpoaccess.gov/usbudget/fy04/pdf/ appendix/dot.pdf. Accessed July 15, 2005, p.747. 
h. Department of Finance, State of California. 2005. Final budget summary: 2005-2006. www.osp.dgs.ca.gov/On-Line+Publications/finalbudsummary0506.htm. Accessed November 3, 2005, pp.146-168.

i. By email from George C. Smith, California Dept. of Transportation, September 26, 2005.

\section{Conclusion}

Every benchmark measure examined indicates transit research in the United States lags research efforts in other modes. This is only partially offset by the emergence and growth of state transit research programs and transit research conducted by UTCs. While the recently enacted SAFETEA-LU partially reverses a long pattern of either declining or stagnant transit research, the increased funding is extensively earmarked to bus technology.

Seventy-five percent of FTA's FY 2006 funding for the National Transit Research Program is earmarked (Townes 2006). Of the earmarked funds applicable to FTA's Strategic Research Plan, 26 percent is directed to the development of electric drive buses. These earmarked expenditures are in addition to the National Fuel Cell Bus Technology Program, funded at $\$ 49$ millions over the next four years. Deploying a fleet of electric drive buses, while important to energy and environmental goals, does little to increase understanding of the determinants of transit use. Without such understanding it is difficult to see how FTA can advance its goal of increasing transit ridership.

As the constitutional body responsible for budgeting, Congress has the legal authority to allocate monies to whichever transit research priorities and organizations it deems appropriate. In doing so, however, Congress must recognize that it risks frustrating administrative processes intended to advance national goals for urban transportation development. Planners and policy-makers at all levels of government are rightfully concerned about the sustainability of energy supplies and environmental quality and a U.S. urban development pattern dependent on auto use. Even assuming the environmental and energy problems associated with urban auto use can be mitigated, it is neither practical nor affordable to build all the highway capacity required to maintain current levels of mobility in our largest cities. Transit ridership will have to increase and more importantly transit mode split must increase. Making this happen requires more research on how to attract choice riders than has historically been the case. 


\section{Acknowledgment}

The research contained in this article was sponsored by the U.S. Department of Transportation, Federal Transit Administration, to foster information exchange. The U.S. government assumes no liability or responsibility for the contents of this article or the use of it.

\section{References}

American Public Transportation Association. 2001. Research and technology strategic plan. http://www.apta.com/about/committees/rsrchtec/documents/ stratpln.pdf. Accessed July 12, 2005.

Committee on Science, Engineering, and Public Policy. 1999. Evaluating federal research programs. Washington, DC: National Academy Press.

Department for Transport. 2000. Transport ten year plan 2000. http://www.dft. gov.uk/stellent/groups/dft_about/documents/page/dft_about_50394404.hcsp\#P148_11869. Accessed July 12, 2005.

. Evidence and research strategy. 2002. United Kingdom. http://www.

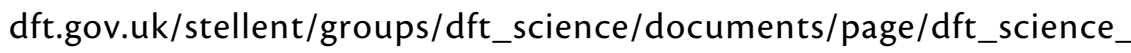
026588-02.hcsp\#TopOfPage. Accessed July 12, 2005.

Division of Research and Innovation. 2000. Strategic research plan: Executive summary. California Department of Transportation. i80.dot.ca.gov/hq/research/ strategicplan/executive_summary/srp_main.htm. Accessed July 15, 2005.

Federal Highway Administration. 2005. Corporate master plan for research and deployment of technology and innovation. Washington, DC. http://www.fhwa. dot.gov/legsregs/directives/policy/cmp/03077.htm. Accessed May 9, 2005.

Federal Railroad Administration. 2002. Five-year strategic plan for railroad research, development, and demonstration. Washington, DC: March.

Federal Transit Administration. 1999. Transit research and technology 5-year plan. Washington, DC: October.

2005. Strategic research plan. Washington, DC: September 30.

Research and Innovative Technology Administration, U.S. Department of Transportation. 2006. UTC Current Program. http://utc.dot.gov/current.html. Accessed November 28, 2006. 
Townes, Michael. 2006. The second letter report of TRB's Transit Research Analysis Committee. Transportation Research Board, March 10. http://trb.org/publications/reports/trac_March_2006.pdf. Accessed April 13, 2006.

Transportation Research Board. 2006. Research in progress. http://rip.trb.org/. Accessed November 28, 2006.

U.S. Department of Transportation. 2003. Strategic plan: 2003-2008. Washington, DC: September.

Volpe National Transportation System Center. 2003. Research, development, and technology plan, 5th ed. Department of Transportation.

Wachs, Martin, and Ann M. Brach. 2004. Earmarking in the U.S. Department of Transportation research programs. Prepared for Annual Meeting, Transportation Research Board, 2005.

\section{About the Author}

RICHARD MARSHMENT (rmarshment@ou.edu) is a professor of regional and city planning at the University of Oklahoma. He has a Bachelor of Science in business administration from Bowling Green State University, a Master of Architecture from the University of New Mexico, and a Ph.D. in urban planning from the University of Washington. Professor Marshment has been an active researcher in transportation planning for many years. His work has appeared in the Journal of Policy Studies, Review of Urban and Regional Development Studies, and the Transportation Research Record. His current research focuses on the economics of rail transit systems. 